The University of San Francisco

USF Scholarship: a digital repository @ Gleeson Library |

Geschke Center

School of Education Faculty Research

School of Education

2011

\title{
Engendering Agency: The Differentiated Impact of Educational Initiatives in Zambia and India
}

Monisha Bajaj

University of San Francisco, mibajaj@usfca.edu

M Pathmarajah

Follow this and additional works at: http://repository.usfca.edu/soe_fac

Part of the Education Commons

\section{Recommended Citation}

Bajaj, M. \& Pathmarajah, M.(2011). Engendering Agency: The Differentiated Impact of Educational Initiatives in Zambia and India. Feminist Formations 23(3), 48-67. The Johns Hopkins University Press.

This Article is brought to you for free and open access by the School of Education at USF Scholarship: a digital repository @ Gleeson Library | Geschke Center. It has been accepted for inclusion in School of Education Faculty Research by an authorized administrator of USF Scholarship: a digital repository@Gleeson Library | Geschke Center. For more information, please contact repository@usfca.edu. 


\title{
Engendering Agency: The Differentiated Impact of Educational Initiatives in Zambia and India
}

\author{
Monisha Bajaj and Meera Pathmarajah
}

Efforts to interrupt the reproduction of unequal gender relations in schools involve alternative practices and pedagogies intended to transform students' notions of gender and gender relations. Beyond the protective environments where such educational initiatives take shape, however, students must rely on their own sense of agency to reenact newly developed gender roles, behaviors, and understandings. This article examines how human agency is differentially experienced and acted upon by boy and girl students responding to educational nongovernmental initiatives in Zambia and India. Two case studies are reviewed, offering evidence from participants in educational programs that seek to deliberately disrupt gender inequality, revealing distinct ways in which boys and girls respond to such efforts. It is argued that structural inequalities tend to privilege boys and enable them to experience more "transformative agency" and efficacy when asserting new understandings of gender and gender relations.

Keywords: agency / civil society / comparative education / development / gender / international education / NGOs / poverty

Various strategies to restructure gender norms have been developed over the past three decades by international and local nongovernmental organizations (NGOs) working to improve gender equality in and through education. Program designs vary widely, from increasing girls' access to schools to textbook reforms to innovative instructional methods and curriculum. While most NGO 
programs maintain a focus on girls only in order to increase their confidence and agency, others deliberately address the critical role that boys and men play in altering and reformulating conceptions of gendered norms and behaviors. This article draws on Deutsch's (2007) framework of "undoing gender" to analyze alternative programs in India and Zambia that seek to disrupt gender inequalities, and it argues that an unintended consequence of such programs is the cultivation of differential agency of boys and girls. While we do not posit this as a problem per se, representative qualitative data from two NGO-run programs are presented to highlight the need for scholars and practitioners to consider the privileged agency of boys in alternative educational efforts. ${ }^{1}$

We chose to focus on India and Zambia because of the high rates of genderbased violence in both countries and the strong presence of development efforts, evidenced by the large proportion of NGOs working in each context broadly and on "women's empowerment" specifically. Despite tremendous differences in size, sociopolitics, history, and culture, India and Zambia prove comparable, given their similar rank in the United Nation's Gender Development Index (I22 and I24, respectively), similar rates of women with secondary education (approximately 26 percent for both countries), and health indicators, such as the percent of births attended by skilled health professionals -47 percent for both countries (UNSD 20IO). Additionally, both countries placed considerable emphasis on increasing educational enrollment (for girls and boys) after independence from Great Britain in the mid-I9oos, resulting in greater access inspired by central policies. Since the I99os, both countries have embarked on economic liberalization and away from the controlled economies they established in the decades following independence. This economic shift toward greater global economic integration has arguably opened the way for the corresponding growth of civil society—domestic and international — that has, in part, advanced a diversity of gender-related efforts in both nations.

While we posit that India and Zambia are comparable, given certain similarities in gender and development issues, we also acknowledge that complex global and local structures interact with and differentially influence experiences of gender and education in each country. In India, for instance, the intersection of caste and gender lends important perspective to an analysis of social and economic mobility. Dalit (so-called untouchable) and Adivasi (rural indigenous) women have illiteracy and school dropout rates considerably higher than national averages. In Zambia, class, geography, and ethnicity also combine to create conditions of exclusion from education, health services, and political participation for certain social groups, such as the rural poor. To combat these gendered disparities in access and participation in schools and society, efforts have been undertaken within Zambia and India that address these multiple disadvantages.

Beyond scholarships and incentives to ensure girls' access to schooling, reforms that seek to upset gender norms have grown in popularity in the field 
of international educational development, as has scholarship on them (Bajaj 20I0; Murphy-Graham 2010; Ross 2007; Shah 2010). As such programs grow and expand, it is important to look at the differentiated agency of girls and boys as they attempt to act upon new understandings of gender and gender relations. In particular, program initiatives working to explore and alter social inequalities often construct safe environments that contrast with the lived realities of program participants. Alternative schools or clubs, for instance, offer provisional spaces where girls and boys may be encouraged to reflect, share experiences, and practice new roles and behaviors. Some residential schools provide similar opportunities on a more continual basis (see Ross, Shah, and Wang in this issue). In both special programs and schools, opportunities to assert agency in contexts outside of the space in which the intervention takes place are mediated by interactions and experiences reflective of unequal social relations. Whether girls and boys confront these realities and act upon newfound beliefs similarly or differently is the focus of this article. We argue that structural inequalities tend to privilege boys in many countries, including India and Zambia, and enable them to experience more transformative agency and efficacy when asserting new understandings of gender and gender relations in households, workplaces, and other settings. ${ }^{2}$

The data presented in this article offer evidence from participants in educational initiatives that seek to deliberately disrupt gender inequality, revealing differential ways in which boys and girls tend to respond to such efforts. Two distinct cases are provided in which local NGOs have sought, through policies and curricula, to transform students' notions of gender: the Umutende School in Ndola, Zambia; and the Institute of Human Rights Education program in numerous schools in India. Both NGO programs place equity and social justice at the core of their organizational missions and deliberately seek to create opportunities for students marginalized by ethnicity, caste, class, religion, and so on to critically analyze the conditions, history, and nature of social exclusion. As an extension of this emphasis, both organizations seek to equalize the status of boys and girls who participate in their programs. As we seek to show through examples from students involved with each organization, the privileged agency of boys becomes apparent during interactions with family and community members, whose expectations of gender roles and relations have not gone through a critical examination as experienced by the youth themselves. We argue that supportive structures at all levels are vital to enabling and sustaining transformations in gendered behavior, and this is perhaps even more crucial in the case of girls to limit the potential for retaliation and backlash when they attempt to act upon their new learnings. 


\section{Relevant Literature}

The conceptual frameworks of "doing gender" (West and Zimmerman 1987) and "undoing gender" (Deutsch 2007) illuminate the potential of human agency in constructing and deconstructing gender. Whereas much research looks at how gender inequality is manifested in social institutions and is experienced differently across time and place, these frameworks emphasize possibilities of change through everyday action and interaction. Applying the undoing gender framework to the realm of schooling, Stromquist and Fischman (2009) and others have discussed how notions of gender and sexuality are reified and/or upset in educational efforts through new practices and policies. This article, instead, looks specifically at how human agency is differentially experienced and acted upon by boys and girls in Zambia and India, and a review of relevant literature will situate the data presented in subsequent sections.

Building upon decades of social research aiming to clarify distinctions between gender and sex, feminist scholarship has interrogated how social actors are "doing gender" in everyday interactions (West and Zimmerman 1987). The doing-gender framework significantly shifts debates away from passive acceptance of the socialization processes and deterministic structural conditions surrounding women's subordinate economic and social roles. It also argues against earlier assumptions of gender as biologically determined based on sex, instead emphasizing gender as an ever-present social activity in which girls and boys, men and women, continually construct, legitimize, and reproduce gender roles and behaviors. This powerful focus on human agency in the doing-gender framework, however, has been sparsely highlighted in gender research, which has concentrated on describing the persistence of unequal gender relations in society (Deutsch 2007).

Recognizing the need to move beyond documenting gender inequality, Deutsch has called upon scholars to search for ways of undoing gender by focusing on resistance and strategies for reducing gender inequalities. Her framework suggests five ways in which reducing gender difference could be examined:

1. instances when social interactions become less gendered, not just differently gendered;

2. the conditions under which gender is irrelevant in social interactions;

3. inquiries into whether all gendered interactions reinforce inequality;

4. examples of how the structural (institutional) and interactional levels might work together to produce change; and

5. interactions as sites of change (II4).

Within each of Deutsch's five areas is an underlying theme of change, seemingly reminiscent of the transformation solicited by feminists in the field of education and development in the I980s. A decade prior, during the I970s, Women in Development (WID) symbolized, quite literally, the inclusion of women 
participants in projects that enabled their access to education, training, credit, land, and employment. However, with its singular focus on unequal access, inequalities pertaining to women's and men's differential decision making and power relations in domestic, professional, and social spaces were left unanalyzed. By the I980s, gender relations increasingly became the focus of analysis. Gender and development (GAD) emerged as a new framework promoting empowerment strategies and the restructuring of traditionally male-dominated institutions (Vavrus and Richey 2003). However, the predominant concern over "gender parity," instead of "gender equality," during the last few decades has shown that shifts in ideology are highly complex and difficult to achieve at the implementation level (this difficulty is also illustrated in Thomas and Rugambwa's article in this issue).

Insights into the possibilities of reducing gender inequality at the programmatic level are explored by Stromquist and Fischman (2009), who highlight educational settings as sites where gender is often reproduced, but also potentially interrupted (Bajaj 2009a; Murphy-Graham 2009). In particular, interactions between educators and students tend to mirror those gendered roles and relationships occurring in settings outside the school, including homes and communities. Thus, deliberate attempts to countervail traditional gender norms at the school level have potentially transformative consequences on gendered roles, behaviors, and expectations at wider societal levels as well. Importantly, these roles and behaviors vary across contexts, and it is crucial that efforts to disrupt gender inequality investigate the intersections of class, race, ethnicity, and religion with gender, while also paying attention to both individual and collective levels of action (Stromquist and Fischman 2009).

Interrupting gendered behaviors is also a function of how well structural realities are understood and effectively altered by those agents seeking to undo gender. Hence agency is essential both for resistance (defying conventional ways) and transgression (developing new behaviors and shaping new realities) (ibid.). However, as this article explores, external realities and relational interactions, including those stemming from one's new consciousness, may also be differently experienced by girls and boys. We focus intentionally on what Stromquist and Fischman (2009) term "transgression" in assessing how language as a marker of identity, along with new behaviors and shifting attitudes, particularly for young men, disrupt notions of gender in new and, arguably, transformative ways.

\section{Methods}

The two case studies of different organizations in Zambia and India are based on research undertaken independently by one of the authors (Bajaj), and through subsequent discussion of the data with the second author (Pathmarajah). Both are South Asian American women (of Indian and Sri Lankan descent, respectively) who have worked in international educational development as scholars 
and practitioners for over a decade. While the data collected were part of doctoral and postdoctoral projects carried out by Bajaj, analysis and discussion with Pathmarajah generated new insights into the differentiated agency of boys and girls. Pathmarajah's experience as a development practitioner for many years working with girls' education programs in India and Sri Lanka offered fresh perspectives on the implications of the data from Indian and Zambian NGOs.

The Zambia research was undertaken during 2003-2004 as part of a larger study on the experience of secondary students living amid economic decline and the HIV/AIDS pandemic. Observations, interviews, focus groups, research diaries, and surveys were carried out at the NGO-run Umutende School and at government secondary schools in Ndola, Zambia. Over ninety secondary students, alumni, teachers, parents, and administrators participated in the qualitative portion of the research, which included regular classroom observations, semi-structured interviews, and focus groups. Youth respondents generally came from low- to middle-income families and were between the ages of I2 and 2o. Extensive participant observation was also utilized, with Bajaj living in the school compound and partaking in daily activities over the ten months in which research was carried out.

Data for the India case study are also based on field research conducted for a larger study undertaken between 2008 and 20Io. This larger study examined rights-based educational initiatives in six states of India, looking at the influence of local programs, pedagogical development, and national policy on students' constructions of identity and citizenship. The data presented come from observations, semi-structured interviews, and focus groups with in 8 teachers; 625 students; 80 staff members, government officials, and activists; and 8 parents. Youth respondents largely belonged to Dalit and Adivasi communities, because most human rights education programs are targeted at marginalized communities, although some respondents came from slightly higher class and caste backgrounds. Respondents ranged in ages from to to 20 , as both current students and alumni of the human rights education program were interviewed. Participant observation also aided in building rapport with students and teachers through summer camps, teacher training, and other organizational events. The notion of agency being differentially experienced by boys and girls surfaced as a core theme of analysis during and after research periods in both sites.

\section{Case Study 1: Inequality and Gender in Zambia}

In Zambia, the realities of gender discrimination not only limit girls' and women's access to education and employment, but they also pose life-threatening dangers, including rape, HIV/AIDS, and domestic violence. An estimated I3.5 percent of the country's adult population (ages 15-49) live with HIV/AIDS, while women comprise 58 percent of adults (ages 15 and above) who are infected (UNAIDS 2009). Domestic violence is common, though often unreported, with 
an estimated 59 percent of women victimized by physical violence at some point during their lifetime (UNSD 20Io). Another study also found that one in six Zambian women have been raped (as cited in HRW 2007), with Zambia ranking I64th out of 182 nations on the United Nations Development Program's (UNDP) Gender Development Index (2010).

The intersection of gender-based discrimination with economic decline in Zambia has made the task of expanding schooling and reversing discriminatory practices particularly difficult. National literacy rates of 7I percent reflect gender disparities, with female literacy at 6I percent, compared to 8I percent for males (UNESCO 2008). While 94 percent of girls attend primary school, only 4I percent of Zambian girls enroll in secondary school (compared to 46 percent of boys) (UNICEF 2008). Furthermore, most young girls face multiple family and social pressures, including risks of teenage pregnancy, early marriage, domestic labor, and parental preference for boys' education when family finances are strained (Byrne 1994; Jensen and Nielsen 1997). Against this unequal backdrop, efforts to improve gender relations are being made in the Zambian Copperbelt region by the Umutende School, the focus of this first case study.

\section{The Umutende School}

"I remember in grade eight [at Umutende], we learned the difference between gender roles and sex roles. Gender roles refer to those which do not have a particular sex. Some would say sweeping is a sex role, meaning it's only for women. But in an actual sense, they are completely wrong. In fact, even men can sweep. For example, as it's practiced here, we don't call workers to clean our classrooms or to sweep our surroundings. We do it ourselves. So I would say this has an impact on us, because even when we reach home, for me, I don't know about the others, I usually clean my own room and wash my own clothes. I don't ask anyone to do it. I let the ladies do their own thing. I do things on my own."

—interview with male high school student (Bajaj 2009a).

As noted above, the policies, pedagogy, and practices of the Umutende Schoola low-cost, nongovernmental private school—are intentionally designed to disrupt gender inequality and to promote values of equity, peace, leadership, nonviolence, and social justice (Bajaj 2009a, 2009b). At the policy level, the school maintains separate campuses for girls and boys, hires only same-sex teachers, and holds longer school days to allow for extra instructional time. The policy of single-sex campuses enables role-modeling for students, and also guards against the common occurrence in Zambia of teacher/student sexual relationships (Bajaj 
2009c; BBC 2003; HRW 2002). Importantly, the creation of separate learning spaces for girls and boys allows for greater participation and leadership development of girls, as was highlighted by the school's founders, since coeducational settings tend to be dominated by boys' participation. Several young women also noted their greater willingness to participate in single-sex classrooms, with one eighth grader noting: "When we are mixed with the boys, they become bullies, so I like [only being with girls] at this school" (Banda 2004). ${ }^{3}$

In contrast to government schools, which have fewer school hours and larger classes among other differentiating factors, Umutende School students participate in community service, mandatory school-cleaning, daily morning assembly, and agricultural production (Bajaj 2009b). The curriculum of the school specifically addresses women's rights, leadership development, goal setting, and other topics promoting messages of equity and social justice. Morning assemblies afford boys and girls opportunities to both assume leadership positions and to freely participate in role-plays and traditionally gendered musical practices (such as drumming that, outside of the school, is restricted to boys). Thus, apart from receiving messages of equality, students proactively participate and engage in practices that defy traditional gender roles, demonstrating how they may transgress conventional gender norms through attitudes, beliefs, and behaviors.

The mandatory activity of school cleaning directly exemplifies one way of undoing gender at the Umutende School. Whereas government schools hire cleaning staff and only occasionally involve, or at times punish, students by making them help clean the school, all boy and girl students at Umutende are required to help clean their respective campuses (Bajaj 2009a). For many students, this redefinition of cleaning as a pervasively gendered role in Zambia was considered a notable aspect of their schooling experience, as indicated in the epigraph at the beginning of this section.

While the policies, pedagogy, and practices of the Umutende School apply equally to both boys and girls, the extent to which students feel able to defy traditional gender roles and behaviors beyond the school campus is likely influenced by a differential sense of agency experienced by boys and girls. For boys, the Umutende School creates unusual compulsory conditions in which sweeping and other cleaning activities must be carried out on a daily basis. Hence the replication of this behavior at home by boys can have profound consequences in altering the division of labor. Young men doing "women's work" was one way of equalizing gendered labor; another way was through deliberate talks and leadership structures that allowed boys to see that girls could also take on traditionally male roles of leadership.

Several young men, in alumni focus groups and interviews with current students, discussed the impact of the school's attempts to alter their understandings of gender roles. For example, a twelfth-grader named Roger noted the following: 
Being an African man, I would have previously said a woman's role is to look after the children and be at home. In the past, women were thought to be second to men. But when you look at it carefully, things are changing. Actually, we've learnt a lot about women's rights here in school. We are taught they are as good as us, probably even better than us (Laughter). I have realized that they can do a lot to improve our nation. So women need to be in roles in society that they have not been in in the past, like as ministers and leaders. (Chewe 2004)

Although data are not available about whether Roger's views on women were sustained over time, the quote above suggests that his schooling experience allowed him to critically reflect on received messages and to question gender inequality in society. Actions taken based on these new attitudes in his home or community would be more likely to affect change, given men's elevated status in most social settings.

In the case of girls, however, transgressing norms or translating lessons on human rights and gender equality into change at home can be more complicated, as it can involve greater risks and harmful consequences. A girl-child without brothers willing to share household chores would be hard pressed to resist participating in cleaning work that is expected of her. Eighth-grader Grace narrated how her agency to influence gender relations in the home and beyond was limited by larger structural conditions working against her continued pursuit of schooling:

Since my father died, most of the family members are depending on my mom. My dad got sick in his late thirties and after he passed away, my mom sent my brother away to boarding school because he was misbehaving a lot. My grandmother is not working, since she's old and my grandfather has retired. My mom's sisters have stopped working because most have fallen sick, have lost their husbands, or don't have education so can't find jobs. My grandfather tried his best to educate them, but some didn't listen. So they all are depending on my mom. My mom has to provide everything for them and most of my cousins. It's very difficult for her. I wish I could grow up in a year so I could have my own job and help my mom out. (Chanda 2004)

Despite the cultivation of alternative lessons related to rights and gender equity, Grace's ability to enact or change micro-level conditions was limited by the strain placed upon her household due to a combination of adverse effects from economic decline, HIV/AIDS, and other material conditions. Perhaps anticipating a future likelihood, given the HIV infection rates and due to her father's untimely death, Grace further noted: "My mom wants me to learn how to live with other people because maybe she might not be there in the future and I'll have no one to look after me." While girls expressed new attitudes about gender relations, as did boys at the Umutende School, girls seemed more 
susceptible to the impact of larger structural forces in terms of caring for the family in times of financial or health crises.

Furthermore, many of the girls at the school were observed to stay on campus for as long as possible, preferring its safety over home and community spaces, where sexual and domestic violence is common (HRW 2007). Whether because of domestic violence in their homes, propositions by "sugar daddies" along the way home, or additional chores due to the death or sickness of a parent related to HIV/AIDS, teachers noted having to coax young women to go home after school hours and especially on half-days. Thus, in light of prevailing cultural and social norms tipped in favor of boys and men, concrete opportunities and support for girls to proactively act upon rights-based knowledge and reconsidered gender roles outside of the Umutende School appeared limited. The school operates largely in isolation from government schools and other state institutions; given donors' attention to increasing girls' access and parity in education, attempts to dismantle unequal gender norms have not been as high a priority on policy makers' agendas. Data from India offer comparative perspectives on similar phenomena emanating from student participation in rights-based instruction.

\section{Case Study 2: Gender Disparities in India}

"If parents are buying something, they just buy it for the boy and not for the girl-child. What parents say is, "Why should I spend money for your studies? You will just be housewives in the future so you don't need to get educated.' That is the reason for female infanticides too, since even if the female child grows up, they are going to go live in someone else's house and the parents don't see the point. Also, when the girl has to get married, the parents have to pay more dowry. So for all these reasons, parents avoid the female child. They don't want a female child. If somehow they know when the child is in the womb, they also go for female feticides."

-Priya Kumar (2009)

Across India's vast population of I.2I billion people, the intersectionality of class and caste trap an estimated 42 percent, or 504 million people, in poverty, earning less than US\$I.25 per day (UNICEF 2009). Highly represented among the poor are Dalits and Adivasis, who comprise over 20 percent of India's population (HRW 2007). Beyond disadvantages linked to class and caste, girls and women (especially those from marginalized groups) face further hardships on account of gender discrimination. National literacy rates are testimony to the pervasiveness of gender inequality in India, with only 65.5 percent of women, 
as compared to 82.I percent of men, literate in the country (GOI 20II). Parents have long preferred boy-children over girls (as noted by the seventh-grade girl in the epigraph above), because of marriage patterns and economic opportunities that favor sons. Gender preference results in an estimated I.5 million cases of female infanticide and feticide each year. The dominance of patriarchy is further manifested in statistics showing 37 percent of women having experienced some form of physical violence at the hands of spouses (NFHS 2006).

The following case study examines the efforts of the Institute of Human Rights Education (IHRE), an NGO in India, working to counter gender violence, along with other forms of marginalization. IHRE utilizes education as a tool for social change, aiming to destabilize longstanding traditions of caste and gender discrimination. While youth transgressing caste and gender norms serves as the intended outcome of IHRE's initiative, we seek to interrogate the agency required to act upon reconceptualized notions of gender that is differentially experienced by boys and girls.

\section{The Institute of Human Rights Education}

The institute grew out of the work of a larger human rights organization, People's Watch. IHRE began working in Tamil Nadu in the late I99os, using schools as a platform to spread human rights education and awareness. Since 1997, more than 300,000 (mostly low-income and low-caste) students have participated in the human rights education program; IHRE has expanded into eighteen states and some 4,000 schools across India, making it the largest NGO program implementing human rights education in India to date. Primarily, IHRE trains teachers to implement a three-year human rights curriculum for sixth, seventh, and eighth graders, addressing topics like constitutional rights, children's rights, and the right to equal treatment irrespective of gender, religion, caste, income, and language, among others. ${ }^{4}$ Of the topics included in the textbooks for children, gender (discrimination, violence, and inequality) is one of the most consistently highlighted, second only to poverty and the right to development. The program is endorsed by state and district educational authorities, who grant permission for school headmasters to send one to two teachers to IHRE's multiple-day training, where experts work to convince teachers about the importance of human rights and orient them to the IHRE-designed textbooks. Following the training, teachers are tasked with conducting one-hour classes twice a week. Apart from this, IHRE has also commenced forming human rights clubs and summer camps for older secondary school students.

While the types of impact IHRE is having on students, teachers, and communities across India is discussed in more depth elsewhere (see Bajaj 20IO, 20I Ia, $20 \mathrm{II}$, 20IIc), of interest in this article is the type of action-oriented responses undertaken, and by whom. Not all students learning IHRE undergo a "transformative experience" that enables transgression, but in instances where they do, the impact has been noteworthy. The responses to human rights education 
range from active intervention in situations of abuse, to reporting violations, to spreading awareness of human rights (Bajaj 20Io). Examples of situations where direct intervention or reporting of abuse related to gender at the household and community level included seeking to stop early child marriage, domestic violence, and dowry. At the level of everyday home interaction, many male students discussed washing their own plates or partaking in other domestic chores after taking the IHRE course in which gender inequalities were highlighted.

Social practices that perpetuate subjugation of women and marginalized groups have been commonly and historically enacted across India. The intensification of gender inequality when compounded by caste and class inequality makes certain groups of women particularly vulnerable in households, schools, and communities. Hence fundamental to girls' agency is the creation of enabling conditions for girls to build their voice, skills, knowledge, and confidence with sustained support over time, combined with structural changes that allow greater representation and participation of women in opportunities and decisionmaking forums that are typically male-dominated.

Boys appear to experience a sense of privileged agency in raising their voice and enabling change in the household. In the very common issue of boys being given more food than girls, the following example narrated by Binayak, an eighth-grade male student participating in a focus group on 9 July 2009 in the state of Orissa, demonstrates how young men can alter household discrimination: "Women and girls are neglected usually and have to take food after all the men and boys have already eaten. In my community in all the households, this is happening. After I learned about human rights in this IHRE course, I told my family and neighbors that 'girls also have rights. We are all equal.' At least within my family, we are now eating together at the same time and equally. I made that change in my house." Binayak was able to act as a change agent to force his family to consider new practices. His role as a male member of his family and his human rights learnings combined to result in a more favorable outcome for the women and girls in his home. Several girls, however, noted attempting to assert their right to an equal share of food or to doing less housework with little success. One of these young women said that her mother beat her after she suggested an alternative division of work, saying "I'll treat you like this only!" (student focus group, II February 2009).

Evidence from an analysis of the impact on students of the IHRE program across five states (Tamil Nadu, Karnataka, Gujarat, Orissa, and West Bengal) confirms that girls and boys respond differently to the program. Whereas a greater percentage of girls showed initiative in spreading awareness about human rights, a higher percentage of boys reported directly intervening in situations of abuse, many of those related to gender inequalities. Figure I illustrates gender differences in the types of actions that boys and girls undertook after studying human rights. All the reported actions were divided into four categories, and then divided by gender to ascertain the frequency. 


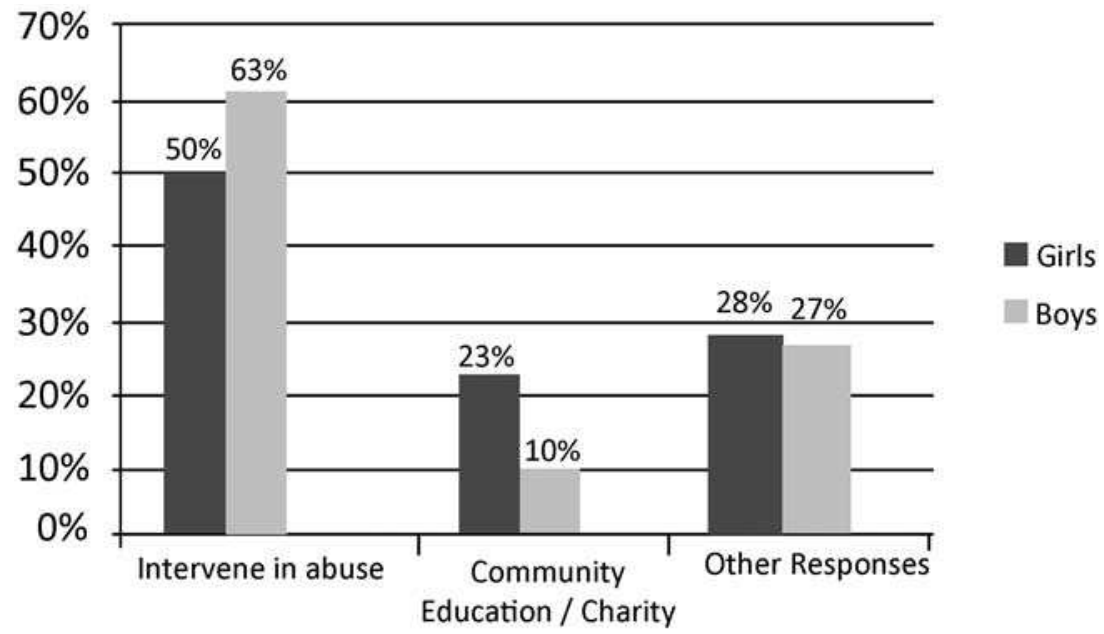

Figure I. IHRE: Analysis of student impact by gender.

The lesser incidence of girls engaging in direct interventions in abusive situations may be due to the perceived and actual risk of retaliation and backlash (sometimes physical) that they might endure when attempting to stop an abuse. Some young women discussed being slapped or beaten by those to whom they stood up, forcing a reconsideration of how to best enact their human rights learnings without jeopardizing their personal safety. Young men also discussed facing physical threats, but girls were perhaps more fearful, given the possibility of rape or other sexual violence and intimidation that has been noted as being prevalent in communities across India (UNDP 2010).

Despite the risks to both boys and girls, boys could often effect change regarding marriage practices that related to caste and gender beyond the classroom. One alumnus of the human rights education program was described in this way by a classmate who ran into him some years later:

My former classmate was passing by and I called him inside. He told me he was getting married and my grandparents who were home asked him, "How much dowry you are going to get from the girl?" He responded to them, saying that, "I studied human rights education just like your grandchild, and we learned that asking dowry is something bad. I won't ask any money from the girl whom I am going to marry." I felt so proud that my friend reacted like this and even more so that he's having an inter-caste marriage. (student focus group, 20 January 2009)

Students' willingness to transgress gender, and sometimes caste, norms as a result of their instruction in human rights suggests the potential efficacy of 
such educational programs for boys, but girls' experiences often differed. Many girls discussed their limited efficacy when trying to renegotiate household norms or intervene in community issues. One eighth-grade girl, Suman, in rural Karnataka noted the following:

In the human rights education textbook, there is a lesson on equality where a woman doesn't bring dowry so the in-laws kill her. I have also seen it in my neighborhood. I overheard some neighbors quarreling and realized the parentsin-law and husband were harassing the new bride for not bringing enough dowry. I went over to their home and told them that demanding money and abusing the woman is against the law. I told them a few times, but they would always tell me it is not my concern and that the parents are doing it for the benefit of their son. One day, my friend was pulled out of school when she was in eighth grade. I tried to tell her parents this is the wrong thing to do and my friend did not want to leave school either, but her parents took her to another village for the marriage without telling anyone. The husband's family was asking for a lot of dowry that her family could not afford. When the groom's family realized she wasn't going to bring enough dowry, they poured kerosene on her and they killed her. It was something that was really bad. (student focus group, I5 June 2009)

Suman learned firsthand about lessons related to gender inequalities and violence by witnessing neighbors and classmates affected by such practices. Her desire to intervene based on human rights knowledge was met with disregard and disinterest, likely ignored because of her status as a young woman of a lower caste and income background. Unable to wield enough authority to convince perpetrators to change their actions, gender violence continued, and her learnings about human rights remained restricted to her textbook and classroom. In many accounts by girls, they soon learned that individual actions were unlikely to produce the desired changes. As a result, they had to consider collective action or had to strategize in how to enlist assistance from individuals with higher status (such as male classmates or teachers), given their limited success in forcing a reconsideration of gendered practices (Bajaj 20I Ib).

India's Right to Education Act that came into force in 2010 creates many openings for monitoring the violation of children's rights and potential avenues for youth to register complaints through state offices of the National Commission for the Protection of Child Rights. These policy initiatives may create an opportunity for youth (both boys and girls) to engage in collective action around gender and caste inequalities, although the level of awareness of these institutions and access to them remains to be determined. 


\section{Discussion and Conclusion}

This article has sought to bring attention to the differentiated experiences of boys and girls when responding to rights-based educational pedagogies and practices intended to produce social change. When boys exert agency, they are doing so within a particular social context in which the voice, influence, and power of males have been traditionally dominant. For girls, translating a newfound sense of equality and respect into agency and action is often encountered with greater retaliation and difficulty. Hence, while acknowledging the transformative potential of education leading to more equalized relations, we point out the need to recognize the privileged agency of boys in acts of resistance (defying conventional ways) and transgression (new behaviors to shape new realities) (Stromquist and Fischman 2009).

Through examples citing student responses to educational initiatives in distinct parts of India and Zambia, we find similar instances where boys, perhaps against their own self-interests, act upon reconceptualized notions of gender, thus defying traditional roles and responsibilities. Such acts demonstrate solidarity and a commitment to equity, although without longitudinal data, it is unclear if such acts are sustained over time.

Undoubtedly, girls are also equally capable and do seek to exert agency, but more often with minimal impact. Experiences of limited efficacy when seeking to transform unequal gender practices and norms that disadvantage them require that they rethink strategies and consider their disparity in voice and status outside the context of alternative instruction. This research suggests that young women may do better collectively or by strategizing together with peers or adults to address abuses, given their limited status in certain locales (Bajaj 20IIC).

For both boys and girls, resistance to convention is contingent upon agency, yet the manifestation of resistance and transgression depends on the social, economic, and cultural context. In particular, the existence of structural factors that unfavorably stifle attempts at defying conventional norms pose a real threat to actual and intended exertions of agency (Kabeer 2002; Maslak 2008). This study notes that agency can be cultivated in NGO programs and in spaces where both boys and girls are involved in educational efforts to undo gender, but that boys may experience greater efficacy in altering norms beyond the classroom or instructional space. At the community level and distinct in each location discussed, the persistence of early marriage for young women, gender violence, and male-dominated institutional structures, among other markers of gender discrimination, signify major social issues that have continued over time and limit young women's ability to act. Undoing gender requires attention to the larger material and structural conditions that shape young people's lives, as well as understanding the sometimes temporal and situational nature of agency when fostered in alternative educational spaces. 
These wider norms and structures surrounding efforts to equalize gender relations require confrontation through multiple mechanisms so that the burden of enacting change does not rest solely on individual agents of change. Instead, efforts to disrupt the status quo are most effective when they work at various levels, from the individual child, to the family, to the community and wider society. Consequently, this requires that agency be conceptualized as one aspect of a wider change process, accompanied by engagement with communities and state institutions, as well as through legislation.

This article considered the privileged agency of boys in two NGO initiatives that sought to deliberately restructure gender relations. As the data on restructuring domestic roles suggest, cooperation and willingness to change is critical from both males and females in order to work toward gender equality and the elimination of discriminatory practices. Social constructions of masculinities can also hamper men's willingness to consider new roles, or to exercise resilience against community backlash when they do. Attention to constructions of masculinity and femininity, as well as locating spaces for fluidity and malleability, is required of any intervention that seeks to disrupt gender inequalities in order to ensure that greater good, rather than greater harm, results from such efforts.

The identification of agency as differentially experienced, influenced, and acted upon by boys and girls is not intended to undermine the need for both boys and girls to take initiative and to act in complementary ways. Doing so, however, often requires significant interaction among young men and women to exchange perspectives and to practice engaging in dialogue in respectful and meaningful ways. Similar to findings in this issue's articles by Thomas and Rugambwa and Muhanguzi, Bennett, and Muhanguzi, such engagement becomes difficult in settings where males traditionally dominate and/or where social interactions between sexes are typically avoided.

Those charged with designing educational programs with alternative gender norms tend to favor coeducational initiatives; however, affinity groups by gender may also be useful in certain situations, or periodically even within coeducational efforts to better equip young women to counter larger social norms. Many empowerment programs designed to interrupt gender inequality do take note of the greater vulnerability that girls and women face in everyday life, and, as a result, utilize collective group processes. Girls' groups and clubs are an increasingly common strategy for bringing girls together to participate in activities designed to develop life skills, human rights awareness, and an understanding of social issues. However, a more deliberate focus on the differentiated agency of each group and the possibility for strategic alliances that seek to undo gender are required (Deutsch 2007).

While much attention has been paid to girls' access to schooling as evidenced in global meetings and agreements, such as the Millennium Development Goals and Education for All, young women's experiences inside and 
outside of schools must also be considered. Education, as Vavrus (2003) has argued, is not a panacea for all social ills, and girls' enrollment in schools- that often have unequal practices and poor quality-will not automatically transform poverty and underdevelopment. Innovative spaces that seek to disrupt larger inequalities from the ground up, utilizing schools as a laboratory for engendering change, are proliferating and can certainly be effective. What happens outside these temporal spaces, however, must be considered by planners and scholars so that girls' agency is cultivated rather than extinguished through frustrated attempts to influence change.

This article highlights the importance of multidimensional interventions and recognizes the differential agency for boys and girls when responding to programs promoting gender equality. Exploring further the intersectionalities of gender with caste and class would offer additional insight into limitations and possibilities for transformative agency among and across groups of boys and girls. The demand for greater participation and collective rights by marginalized groups has the potential to create solidarity among men and women within such movements. At the same time, however, the question of equality must be reflexively applied to ask whether individuals within such groups are treating their own members with equal respect and opportunity. Demanding greater collective equality without agitating for equal treatment between both sexes within progressive movements requires further attention.

Deutsch's (2007) framework offers a window into understanding how agency can ensue from recasting gender as a relational and fluid process rather than a biological given. Continued application of Deutsch's model, particularly to the educational experiences of youth, can strengthen our understanding of how gender can slowly "come undone," as well as identify sites of resistance and new formations. Through applying this framework, like shining light through a prism, a variety of insights emerge related to the differentiated agency of boys and girls, the need for collective action to enhance girls' status and agency, and the relationship between classrooms and communities, for newly learned norms in the former to influence realities in the latter. Greater attention to efforts to transform gender relations in schools and beyond can inform our understandings of how, albeit incrementally, social change might occur. Understanding and ultimately dismantling structures that sanction and perpetuate structural and physical violence are central for scholars and practitioners in international educational development concerned with social justice broadly, and gender equity specifically.

\section{Acknowledgments}

The authors would like to express their gratitude to the organizations highlighted in this article for extending access and facilitating the data-collection process. They also appreciate the comments provided by the special issue co-editors and anonymous reviewers to strengthen the article. 
Monisha Bajaj is an assistant professor of education in the international and comparative education programs at Teachers College, Columbia University. She is the editor of the Encyclopedia of Peace Education (2008), and the author of Schooling for Social Change: The Rise and Impact of Human Rights Education in India (20II). She can be reached at bajaj@tc.edu.

Meera Pathmarajah is a doctoral student at Teachers College, Columbia University. Her research interests, which include gender and education, teacher training, and youth leadership, stem from her experiences with educational programming in South and Southeast Asia, as well as with the organization she founded, Visions Global Empowerment. She can be reached at mpathmar@gmail.com.

\section{Notes}

1. This article builds on Bajaj's (2009a) previous examination of efforts to undo gender at a Zambian school, published in a special issue of the International Review of Education dedicated to the same theme. In subsequent research and discussions among the authors of this work, the differential agency of boys and girls came to light in their participation in these efforts to reconstitute gender relations in NGO projects in India and Zambia. As such, this work draws on the prior article on Zambia, although no ideas or sections have been borrowed without citation. The conceptual sections have been significantly reworked, drawing on larger development discourses around gender, and comparative data from India has been juxtaposed with findings from Zambia.

2. The concept of transformative agency draws on Freirean (1970) notions of "critical consciousness," and how students can respond to schooling and other educational interventions in ways that activate their desire to influence positive social change through individual and collective actions (Bajaj 2009b; Giroux 1988; Noguera 2003).

3. All participants in this study have been assigned pseudonyms to protect confidentiality.

4. In India, grades are referred to as "standards" or "classes." Class I students are generally age 6 and class 12 students are generally age 17 , thus corresponding with international educational norms. For ease of comparison, we have used "grade" here instead of the local terms.

\section{References}

Bajaj, Monisha. 2or ra. "Human Rights Education: Ideology, Location, and Approaches." Human Rights Quarterly 33(2): 48I-508.

_. 2orrb. "Teaching to Transform, Transforming to Teach: Exploring the Role of Teachers in Human Rights Education in India." Educational Research 53(2): 207-2I.

- 20Irc. Schooling for Social Change: The Rise and Impact of Human Rights Education in India. New York: Continuum Publishing.

—. 2010. "From 'Time Pass' to Transformative Force: School-Based Human Rights Education in Tamil Nadu, India." International Journal of Educational Development. 
Accessed I December 20Io. <http://www.elsevier.com/wps/find/journaldescription .cws_home/7ig/description>.

- 2009a. "Un/doing Gender? A Case Study of School Policy and Practice in Zambia." International Review of Education 55(5-6): 483-502.

_. 2009b. "I Have Big Things Planned for My Future': The Limits and Possibilities of Transformative Agency in Zambian Schools. Compare: A Journal of Comparative and International Education 39(4): 55I-68.

- 2009c. "Sugar Daddies and the Danger of Sugar: Cross-Generational Relationships, HIV/AIDS, and Secondary Schooling in Zambia." In International Perspectives on Education and Society. Vol. Io, Gender, Equality, and Education from International and Comparative Perspectives, ed. David P. Baker and Alexander W. Wiseman, I23-44. Bingley, UK: Emerald Group Publishing.

Banda, Lucy. 2004. Personal interview with author, 4 June.

British Broadcasting Corporation (BBC). 2003. Teacher-Pupil Sex Blamed for HIV Rise.

Accessed I8 February 2008. <http://news.bbc.co.uk/2/hi/world/africa/328I6rg.stm>.

Byrne, Bridget. 1994. Gender Profile of Zambia. Brighton, UK: BRIDGE, Institute of

Development Studies, University of Sussex.

Chanda, Grace. 2004. Personal interview with author, 24 June.

Chewe, Simon. 2004. Personal interview with author, 23 June.

Deutsch, Francine. 2007. "Undoing Gender." Gender Eु Society 2I(I): I06-27.

Freire, Paulo. 1970. Pedagogy of the Oppressed. New York: Continuum Publishing.

Giroux, Henry. 1988. Schooling and the Struggle for Public Life: Critical Pedagogy in the Modern Age. Minneapolis: University of Minnesota Press.

Government of India (GOI), Ministry of Home Affairs. 20I I. Census of India 201 I. Accessed I5 March 20II. <http://censusindia.gov.in/>.

Human Rights Watch (HRW). 2007. Hidden Apartheid: Caste Discrimination against India's "Untouchables." New York: HRW.

-2002. Hidden in the Mealie Meal: Gender-Based Abuses and Women's HIV Treatment in Zambia. New York: HRW.

Jensen, Peter, and Helena S. Nielsen. 1997. "Child Labour or School Attendance? Evidence from Zambia." Journal of Population Economics Io(4): 407-24.

Kabeer, Naila. 2002. The Power to Choose: Bangladeshi Women and Labour Market Decisions in London. London: Verso.

Kumar, Priya. 2009. Personal interview with author, 30 January.

Maslak, Mary Ann, ed. 2008. The Structure and Agency of Women's Education. Albany: State University of New York Press.

Murphy-Graham, Erin. 2010. "And When She Comes Home? Education and Women's Empowerment in Intimate Relationships." International Journal of Educational Development 30(3): 320-3I.

- 2009. "Constructing a New Vision: Undoing Gender through Secondary Education in Honduras." International Review of Education 55(5-6): 503-2I.

National Family Health Survey (NFHS). 2006. India. Accessed 8 March 20I I. <http:// www.nfhsindia.org/pdf/India.pdf>.

Noguera, Pedro. 2003. City Schools and the American Dream: Reclaiming the Promise of Public Education. New York: Teachers College Press. 
Ross, Heidi A. 2007. "Policy as Practice, Agency as Voice, Research as Intervention: Imag(in)g Girls' Education in China." In The Structure and Agency of Women's Education, ed. Mary Ann Maslak, 233-52. Albany: State University of New York Press.

Shah, Payal P. 20ı.. "The Kasturba Gandhi Balika Vidyalaya (KGBV) Program, Gujarat: Fostering Spaces for Empowerment? An Ethnographic Investigation.” Paper presented at the Comparative and International Society Meeting, 3 March, Chicago.

Stromquist, Nelly P., and Gustavo E. Fischman. 2009. "Introduction-From Denouncing Gender Inequities to Undoing Gender in Education: Practices and Programmes Toward Change in the Social Relations of Gender." International Review of Education 55(5): 463-82.

United Nations Children's Fund (UNICEF). 2009. India: Statistics. Accessed 23 May 20I I. <http://www.unicef.org/infobycountry/india_statistics.html>. . 2008. Zambia: Statistics. Accessed 8 January 20I . <http://www.unicef.org/ infobycountry/zambia_statistics.html>.

United Nations Development Programme (UNDP). 20I0. Gender Development Index, Human Development Report. New York: United Nations.

—. 2009. "Human Development Report 2009: Gender-Related Development Index and Its Components." GDI rank: Zambia. Accessed 8 January 2or I. $<$ http://hdrstats .undp.org/en/indicators/II3.html>.

United Nations Educational, Scientific and Cultural Organization (UNESCO), Institute of Statistics. 2008. National Adult Literacy Rates ( $\left.5^{+}\right)$. Accessed 8 January 201 I. $<$ http://stats.uis.unesco.org/unesco/TableViewer/tableView.aspx?ReportId=210 $>$.

United Nations Programme on HIV/AIDS (UNAIDS). 2009. HIV and AIDS Estimates (2009). Accessed 8 January 20I. <http://www.unaids.org/en/regionscountries/ countries/zambia/\#I>.

United Nations Statistics Division (UNSD). 20I0. The World's Women 20I0: Trends and Statistics. Accessed 8 January 201 I. <http://unstats.un.org/unsd/demographic/ products/Worldswomen/wwVaw2oro.htm>.

Vavrus, Frances K. 2003. Desire and Decline: Schooling Amid Crisis in Tanzania. New York: Peter Lang.

— Reconceptualizing Practice." Women's Studies Quarterly 3I(3-4): 6-I8.

West, Candace, and Don H. Zimmerman. 1987. "Doing Gender." Gender $\mathcal{E}$ Society I(2): I25-5I. 